\title{
Differences In The Properties of Extracellular Polymeric Substances Responsible For PAH Degradation Isolated From Mycobacterium Gilvum SN12 Grown On Pyrene And Benzo[a]pyrenee
}

Chunyun Jia ( $\nabla$ jiachunyun@iae.ac.cn )

Institute of Applied Ecology, Chinese Academy of Sciences https://orcid.org/0000-0001-6086-1206

Changfeng Liu

Shenyang University of Chemical Technology

Zongqiang Gong

Institute of Applied Ecology Chinese Academy of Sciences

Xiaojun Li

Institute of Applied Ecology Chinese Academy of Sciences

Zijun Ni

Institute of Applied Ecology Chinese Academy of Sciences

\section{Research Article}

Keywords: EPS, composition, emulsifying activity, morphology, PAHs

Posted Date: November 22nd, 2021

DOI: https://doi.org/10.21203/rs.3.rs-1074074/v1

License: (c) (1) This work is licensed under a Creative Commons Attribution 4.0 International License. Read Full License

Version of Record: A version of this preprint was published at Archives of Microbiology on March 30th, 2022. See the published version at https://doi.org/10.1007/s00203-022-02849-2. 


\section{Abstract}

To evaluate the differences in the characteristics of extracellular polymeric substances (EPS) secreted by Mycobacterium gilvum SN12 (M.g. SN12) cultured on pyrene (Pyr) and benzo[a]pyrene (BaP), heating method was used to extract EPS from M.g. SN12, and the composition, emulsifying activity and morphology of EPS extracts were investigated in this study. It was indicated that EPS extracts varied significantly with the addition of Pyr or BaP to the bacterial cultures. Concentration of proteins and carbohydrates, the main components of the EPS extracts, first increased and then decreased, with an increase in the concentration of $\operatorname{Pyr}\left(0-120 \mathrm{mg} \mathrm{L}^{-1}\right)$ and $\mathrm{BaP}\left(0-120 \mathrm{mg} \mathrm{L}^{-1}\right)$. A similar trend was observed for the emulsifying activity of the EPS extracts. EPS extracted from all cultures exhibited a compact structure with smooth surface, except EPS extracted from BaP-grown M.g. SN12, which exhibited a more fragile and softer surface. These findings suggest that Pyr and BaP had different influence on the properties of isolated EPS, providing insights into the mechanism underlying PAH biodegradation by some bacteria secreting EPS. To the best of our knowledge, this is the first report on the texture profile of EPS samples extracted from M.g. SN12 grown on PAHs.

\section{Introduction}

Polycyclic aromatic hydrocarbons (PAHs) are associated with adverse effects on human health, and biological remediation is considered as a promising method for removing these contaminants from the environment. Bioremediation of PAH-contaminated soil, especially the bioremediation method combining plants and microorganisms, has recently garnered attention because of cost-effectiveness, better results, no secondary pollution, and the potential of treating large areas with low PAH concentrations (Johnsen et al. 2005; Gan et al. 2009; Haritash and Kaushik 2009). The role of microorganisms in the rhizosphere is crucial for PAH bioremediation. This is because extracellular polymeric substances (EPS), which are secreted by microorganisms, come in direct contact with PAHs on the surface of soil particles and provide a unique conduit for PAH detachment to allow them reach the cell wall of microorganisms. Hence, EPS play a crucial role in PAH elimination during environmental remediation.

Furthermore, EPS improve the binding affinity of microorganisms to PAHs and thus the rate of PAH biodegradation (Urai et al. 2006; Guibaud et al. 2009; Jia et al. 2011). This is primarily because of their use as bioemulsifiers, which can efficiently emulsify PAHs over a wide range of temperatures, $\mathrm{pH}$, and salinity (Zheng et al. 2011). Liu et al. (2001) reported that EPS extracted from a bacterial strain isolated from the waste site of a manufactured gas plant enhanced the release of soil-bound phenanthrene in 24 $h$ (Liu et al. 2001). Furthermore, previous studies suggest that the interaction between EPS and phenanthrene is spontaneous, exothermic, and dominated by hydrophobic interactions and electrostatic forces (Pan et al. 2010; Bai et al. 2016; Tian et al. 2019). These findings suggest that EPS can enhance the release of soil-bound PAHs through emulsification, hydrophobic interactions, and electrostatic forces, and therefore, improve the bioavailability of PAHs. Nevertheless, previous studies did not evaluate the variations in EPS characteristics that are responsible for improving PAH biodegradation in soil. 
EPS include microbial products located on or outside their cell surface and are composed of a variety of organic substances, with carbohydrates and proteins as major constituents, and humic-like substances, uronic acids, and nucleic acids present in smaller quantities (Cescutti et al. 1999; Sheng et al. 2005; Aguilera et al. 2008; Bourven et al. 2012). EPS exhibit strong binding affinity for metal ions and organic pollutants because they contain both hydrophobic and hydrophilic regions in their structures (Sheng et al. 2008; Tourney et al. 2009; Zhang et al. 2009). Therefore, microorganisms produce EPS to protect themselves against unfavourable conditions, such as the presence of toxic substances (Aquino and Stuckey 2004; Henriques and Love 2007; Tourney et al. 2009; Ghosh and Mukherji 2021). Till date, only one study reported that the addition of diesel oil $(0.1 \%, \mathrm{v} / \mathrm{v})$ in the culture medium resulted in emulsification values higher than those obtained without hydrocarbons, under aerobic conditions (Castellane et al. 2017). Thus, to understand the role of EPS, isolated from microorganisms exposed to different type of PAHs, in the process of PAH biodegradation, it is necessary to evaluate the characteristics of EPS secreted by highly efficient PAH-degrading microorganisms in the presence of PAHs.

Several techniques, including colorimetric analysis, scanning electron microscopy (SEM), transmission electron microscopy (TEM), Fourier transform-infrared spectroscopy (FTIR), three-dimensional excitationemission matrix fluorescence spectroscopy (3DEEM), and nuclear magnetic resonance (NMR), have been proposed for characterizing EPS (Liang et al. 2010; Bourven et al. 2012; Lee et al. 2013). Although conventional colorimetric analyses are used to determine the primary components in EPS (Frølund et al. 1995; González-González et al. 2011), methods and techniques, such as TEM, FTIR, and 3DEEM, provide more information about the characteristics and environmental behaviour of EPS (Liang et al. 2010; Zhu et al. 2012; Lee et al. 2013). However, there is limited information on the characteristics of EPS isolated from bacteria growing on PAHs, although EPS characterization has been well documented.

Therefore, the objective of this study was to characterize different EPS samples isolated from a highly efficient PAH-degrading bacterial strain in the presence of pyrene (Pyr) and benzo[a]pyrene (BaP) using batch experiments and a spectral approach. To this end, heat was used to extract EPS from cultures grown on different concentrations of Pyr and BaP, and their characteristics were evaluated using SEM, FTIR, 3D-EEM, SDS-PAGE, and conventional colorimetric analyses. The findings of this study will provide insights into the response of EPS in the presence of PAHs.

\section{Materials And Methods}

\subsection{Growth of Mycobacterium gilvum SN12}

M. gilvum SN12 (M.g. SN12), isolated from the soil collected from the Shenfu irrigation area, Liaoning Province, China, was used as the PAH-degrading strain in this study. This strain was identified using $16 \mathrm{~S}$ rDNA sequence analysis (GenBank accession number: DQ512892), and cultured in a basic medium (BM; $\mathrm{pH}$ : 7.0-7.2), containing $3 \mathrm{~g}$ beef grease, $10 \mathrm{~g}$ peptone, and $5 \mathrm{~g} \mathrm{NaCl}$ in $1 \mathrm{~L}$ of the solution. Active inoculums obtained after successive transfers in BM were sub-cultured by agitating at $150 \mathrm{rpm}$ on a 
rotary shaker at $30^{\circ} \mathrm{C}$ for $5 \mathrm{~d}$. Subsequently, to ensure that the cells grow on PAHs, $1 \%$ of the pre-cultured $\mathrm{BM}$ was transferred into fresh $\mathrm{BM}$ and mineral salt medium (MM), containing different concentrations (2, $5,10,20,40,80$, and $120 \mathrm{mg} \mathrm{L}^{-1}$ ) of Pyr (Fluka, Germany) or BaP (Fluka), respectively, under same conditions for the next $3 \mathrm{~d}$ for culturing. The composition of $\mathrm{MM}$ was as follows (per $\mathrm{L}$ ): $0.5 \mathrm{~g}$ yeast extract, $5 \mathrm{~g} \mathrm{NaCl}, 10 \mathrm{~g} \mathrm{NH}_{4} \mathrm{NO}_{3}, 5 \mathrm{~g} \mathrm{~K}_{2} \mathrm{HPO}_{4}, 5 \mathrm{~g} \mathrm{KH}_{2} \mathrm{PO}_{4}, 0.2 \mathrm{~g} \mathrm{MgSO}_{4} \cdot 7 \mathrm{H}_{2} \mathrm{O}$, and $0.5 \mathrm{~g}$ glucose. The $\mathrm{pH}$ of $\mathrm{MM}$ was adjusted to 7.0, resulting in $30 \mathrm{~mL}$ of $\mathrm{MM}$ supplemented with Pyr or BaP for PAH degradation culture. PAH concentrations in cultures were calculated using the initial amounts of PAH added to the cultures. All experiments were performed in triplicates, according to Sack et al. (1997).

Inoculums were obtained by centrifuging the culture suspensions at the exponential phase and then washing them thrice with sterile water. The initial concentrations of the liquid inoculums were maintained at $0.50 \pm 0.02 \mathrm{~g}$ dry weight $\mathrm{L}^{-1}$. The flasks were incubated on a rotary shaker $(150 \mathrm{rpm})$ at $30^{\circ} \mathrm{C}$ in the dark, under aerobic conditions. For all assays, lasks containing no PAH were used as the controls.

\subsection{Isolation and purification of EPS}

When the PAH-degrading strains reached the stationary growth phase after $5 \mathrm{~d}$, the culture solutions were centrifuged at $5000 \mathrm{rpm}$ for $10 \mathrm{~min}$ at $4^{\circ} \mathrm{C}$ and then re-suspended in sterile water (Castellane et al. 2017). Subsequently, the suspensions were washed twice and separated into two fractions: precipitate and supernatant. Thermal treatment was used to extract EPS from the precipitates; EPS were extracted by adding $0.05 \%(\mathrm{w} / \mathrm{v}) \mathrm{NaCl}$ solution to the precipitates, which were then placed in a water bath at $60^{\circ} \mathrm{C}$ for $30 \mathrm{~min}$. The proportion of $\mathrm{NaCl}$ solution and precipitate was $100 \mathrm{~mL} \mathrm{~g}^{-1}$ ( $\mathrm{Li}$ and Yang 2007).

After the completion of each assay, EPS were isolated from the residual strains using centrifugation $(10,000 \mathrm{rpm})$ at $4^{\circ} \mathrm{C}$ for $15 \mathrm{~min}$. The final EPS supernatant was filtered using a $0.22 \mu \mathrm{m}$ cellulose acetate membrane under sterile conditions, and the filtrate was purified in ultra-pure water using a dialysis membrane (CelluSep 3,500 D membrane; Beijing Jingke Hongda Biotechnology Co., Ltd., Beijing, China) for $48 \mathrm{~h}$, with water removed every $5 \mathrm{~h}$. All low-molecular weight organic compounds and inorganic ions present in the growth medium were removed during purification. Dialyzed EPS were considered pure and stored at $4^{\circ} \mathrm{C}$ for a maximum of four weeks until analyses.

\subsection{Analysis of the composition of different EPS extracts 2.3.1 Conventional chemical analysis}

Total extractable EPS was quantified using total organic carbon (TOC) values, which were measured using a TOC analyser (Multi N/C 3000; Analytik Jena AG, Jena, Germany). The concentrations of proteins, carbohydrates, humic-like substances, and nucleic acids in the EPS extracts were determined using colorimetric methods. The concentrations of proteins and polysaccharides were determined using the Coomassie brilliant blue method, with bovine serum albumin as the standard (Zhang and Dong 2008), and the anthrone method, with glucose as the standard (Frølund et al. 1995), respectively. Modified Lowry method, with humic acid as the standard, was used to determine the content of humic-like substances 
(Frølund et al. 1996), whereas DNA content was determined at $260 \mathrm{~nm}$ using a UV-2100 spectrophotometer (Unico Instrument Co., Ltd., Shanghai, China) (Frølund et al. 1995).

\subsubsection{FTIR analysis}

Aliquots of the EPS extracts were freeze-dried at $-70^{\circ} \mathrm{C}$ for $24 \mathrm{~h}$. Subsequently, the powdered EPS samples were mixed with dry $\mathrm{KBr}$ in a ratio of 1:100 $(\mathrm{w} / \mathrm{w})$ and homogenized in an agate grinder. The functional groups in EPS were identified in the range of $400-4,000 \mathrm{~cm}^{-1}$ using an FTIR spectrophotometer (510FT; Beijing Rayleigh Analytical Instrument Corp., Beijing, China). The scanning parameters included 32 scans, with a resolution of $4 \mathrm{~cm}^{-1}$ (Hong et al. 1999), and the spectra obtained were baseline corrected using the software OriginPro 8 (OriginLab Corp., Northampton, MA, USA).

\subsubsection{DEEM}

3DEEM fluorescence intensities of EPS extracts were measured using the scan mode of a fluorescence spectrophotometer (CARY Eclipse; Varian Co., USA). The excitation-emission matrices (EEMs) were determined for each sample using subsequent scans of emission spectra from $250 \mathrm{~nm}$ to $550 \mathrm{~nm}$ at 2 $\mathrm{nm}$ increments by varying the excitation wavelength from $220 \mathrm{~nm}$ to $500 \mathrm{~nm}$ at $5 \mathrm{~nm}$ increments. The scan rate for each EEM was $1,200 \mathrm{~nm} \mathrm{~min}^{-1}$, and the fluorescence response to a blank solution (doubledistilled water) was subtracted from the fluorescence of each sample. EEM data were obtained using the Cary Eclipse software, where the $\mathrm{x}$ - and $\mathrm{y}$-axes represented the emission spectra and the excitation wavelength, respectively.

\subsection{SDS-PAGE of EPS extracts}

SDS-PAGE was used to resolve the extracellular proteins of M.g. SN12 using a BioRad Mini-Protean Tetra Electrophoresis system, according to the modified protocol of Laemmli (1970). To determine the extracellular proteins in EPS extracts, the proteins isolated from M.g. SN12 and M.g.SN12 growing on Pyr or BaP before and after EPS extraction were analysed. The molecular weights of proteins in all samples were determined using a previously described method (Jia et al. 2017). However, in this study, the gels were destained overnight in a solution containing $25 \%$ ethanol and $8 \%$ acetic acid.

\subsection{Emulsifying activity of EPS extracts}

Emulsification assays on EPS extracts were performed according to Moretto et al. (2015). Aqueous solutions of EPS were mixed with liquid paraffin oil (purchased from a local market) in a 2:3 (v/v) ratio, vortexed to homogeneity, and then allowed to stand at $25^{\circ} \mathrm{C}$ for $24 \mathrm{~h}$. The emulsifying activity of EPS extracts was expressed using the emulsification index $\left(E_{24}, \%\right)$, which was determined using the following equation: $E_{24}=\left(h_{e} / h_{T}\right) \times 100$, where $h_{e}(m m)$ represents the height of the emulsion layer and $h_{T}(m m)$ represents the overall height of the mixture.

\subsection{Structural observations of different EPS in EPS- producing M.g. SN12}


Different cultures of M.g. SN12, between stationary and decline phases, were centrifuged $(1,000 \times g)$ at $4^{\circ} \mathrm{C}$ for $5 \mathrm{~min}$. The isolated cells were washed twice with distilled water to remove residual nutrient components. The distribution of EPS surrounding the cells was observed using a transmission electron microscope (JEM-1200EX; JEOL, Japan). All the EPS-producing isolates were also observed using a fieldemission scanning electron microscope (JSM-7001F; JEOL).

\subsection{Data analyses}

Data were presented as arithmetic mean \pm standard deviation of three replicates, and analysed using Microsoft Excel 2016. Graphs were generated using the software (OriginLab Corp.) Statistical analyses were performed using SPSS 20.0 (SPSS Inc., Chicago, IL, USA). One-way analysis of variance (ANOVA), followed by LSD comparison test $(p<0.05)$ or independent-samples $t$-test $(p<0.05)$, was used to determine significant differences, at $p<0.05$, unless otherwise indicated.

\section{Results And Discussion}

\subsection{Component analysis of EPS extracted from M.g. SN12 grown on PAHs}

\subsubsection{Variations in EPS contents under different PAH concentration}

The yield of EPS extracted from M.g. SN12 exposed to different concentrations of Pyr and BaP are shown in Figure 1(a). The highest EPS yields of $1,005.6 \mathrm{mg} \mathrm{L}^{-1}$ and $876.2 \mathrm{mg} \mathrm{L}^{-1}$ were obtained with media supplemented with $80 \mathrm{mg} \mathrm{L}^{-1}$ Pyr and $20 \mathrm{mg} \mathrm{L}^{-1} \mathrm{BaP}$, respectively. Furthermore, EPS production increased to $1,005.6 \mathrm{mg} \mathrm{L}^{-1}$ at Pyr concentrations of $<80 \mathrm{mg} \mathrm{L}^{-1}$ and then rapidly decreased to $481.5 \mathrm{mg}$ $\mathrm{L}^{-1}$ at a concentration of $120 \mathrm{mg} \mathrm{L}^{-1}$ Pyr. Similarly, EPS production increased at BaP concentrations $<20$ $\mathrm{mg} \mathrm{L}^{-1}$ and declined at higher concentrations. Additionally, the yield of EPS extracted from Pyr-grown M.g. SN12 was more than that from BaP-grown M.g. SN12. Moreover, EPS yield was markedly different in the control (M.g. SN12 grown in medium without PAHs). By contrast, incubation at various concentrations of PAHs ( $<80 \mathrm{mg} \mathrm{L}^{-1}$ Pyr and $40 \mathrm{mg} \mathrm{L}^{-1} \mathrm{BaP}$ ) exhibited a strong stimulating effect on EPS production. Similar results were reported by Castellane et al. (2017), wherein maximum EPS yield $\left(5.26-5.52 \mathrm{~g} \mathrm{~L}^{-1}\right)$ was obtained $96 \mathrm{~h}$ after the addition of $0.1 \%(\mathrm{v} / \mathrm{v})$ diesel oil to the culture, and a significant increase $(p<0.05)$ of $22.4 \%$ in EPS production was observed in the medium supplemented with diesel oil compared with the control (without diesel oil) (Castellane et al. 2017). In addition, a previous study reported that EPS concentration increased from $5.27 \mathrm{mg} \mathrm{g}^{-1}$ to $16.24 \mathrm{mg} \mathrm{g}^{-1}$ with an increase in quinoline concentration from $100 \mathrm{mg} \mathrm{L}^{-1}$ to $500 \mathrm{mg} \mathrm{L}^{-1}$, with a similar increase observed in EPS concentration with increasing pyridine concentrations (Oberoi and Philip 2018). In these studies, the initial concentration of pollutants significantly affected the production of EPS. However, the structure and characteristics of these pollutants were remarkably different, as diesel oil is composed of alkanes with 
15-18 carbon atoms, whereas quinoline and pyridine are heterocyclic aromatic hydrocarbons and PAH consists of at least two benzene rings. Therefore, the effects of PAHs on bacterial growth and EPS production were significantly different from those of diesel oil and heterocyclic aromatic hydrocarbons.

Figure 1(b) and 1(c) summarize the composition of EPS extracted from M.g. SN12 grown on different concentrations of PAHs. It was observed that carbohydrates, proteins, and humic-like substances were the major components of EPS, whereas DNA was present in lesser amounts in all the samples. In EPS extracted from Pyr-grown M.g. SN12, the concentration of each component increased with an increase in Pyr concentration, except for EPS extracted from M.g. SN12 grown on $120 \mathrm{mg} \mathrm{L}^{-1}$ Pyr.

Highest concentrations of proteins $\left(292.4 \mathrm{mg} \mathrm{L}^{-1}\right)$ and carbohydrates $\left(555.3 \mathrm{mg} \mathrm{L}^{-1}\right)$ were observed in EPS extracted from bacteria grown on $80 \mathrm{mg} \mathrm{L}^{-1} \mathrm{Pyr}$, whereas those of humic-like substances $(191.0 \mathrm{mg}$ $\mathrm{L}^{-1}$ ) and DNA (4.1 $\mathrm{mg} \mathrm{L}^{-1}$ ) were observed in EPS extracted from M.g. SN12 grown on $40 \mathrm{mg} \mathrm{L}^{-1}$ Pyr. A similar trend in EPS composition was observed for BaP-supplemented media. With an increase in $\mathrm{BaP}$ concentration from 0 to $20 \mathrm{mg} \mathrm{L}^{-1}$, the protein and carbohydrate concentrations increased from $197.1 \mathrm{mg}$ $\mathrm{L}^{-1}$ to $344.9 \mathrm{mg} \mathrm{L}^{-1}$ and from $309.7 \mathrm{mg} \mathrm{L}^{-1}$ to $536 \mathrm{mg} \mathrm{L}^{-1}$, respectively. However, protein and carbohydrate concentrations decreased when BaP concentrations increased from $20 \mathrm{mg} \mathrm{L}^{-1}$ to $120 \mathrm{mg}$ $\mathrm{L}^{-1}$. Furthermore, the total concentration of each component in EPS extracted from BaP-grown M.g. SN12 was less than that of the components in EPS extracted from M.g. SN12 grown on the same concentration of Pyr. Therefore, the concentrations of Pyr and BaP considerably affected the concentration of each component in EPS.

In both PAHs, proteins and carbohydrates constituted the major components of EPS, and the concentrations of these two components first increased and then decreased with the increasing PAH concentration. Nevertheless, the concentrations of proteins and total sugars in EPS extracted from SEMIA 4080 increased after the addition of $0.1 \%$ diesel oil to the medium, whereas no variations were observed in their concentrations in EPS extracted from the strain MUTZC3 (Castellane et al. 2017). A previous study reported that protein and polysaccharide contents in soluble microbial products (SMP) increased from $2.3 \pm 0.74 \mathrm{mg} \mathrm{L}^{-1}$ to $66.4 \pm 1.68 \mathrm{mg} \mathrm{L}^{-1}$ and from $16.8 \pm 0.12 \mathrm{mg} \mathrm{L}^{-1}$ to $18.0 \pm 0.19 \mathrm{mg} \mathrm{L}^{-1}$, respectively, upon exposure to increasing concentrations of 2,6-dichlorophenol up to $20 \mathrm{mg} \mathrm{L}^{-1}$, and the proteins in SMP were more sensitive to 2,6-dichlorophenol than polysaccharides ( $\mathrm{Li}$ et al. 2016). Furthermore, the concentration of proteins and polysaccharides increased with an increase in pyridine concentration from $100 \mathrm{mg} \mathrm{L}^{-1}$ to $1,000 \mathrm{mg} \mathrm{L}^{-1}$, with more polysaccharides than proteins in EPS, and the concentration of proteins, which constituted the major component of EPS, increased at quinoline concentrations of $<500 \mathrm{mg} \mathrm{L}^{-1}$ (Oberoi and Philip 2018).

In this study, the ratio of proteins to carbohydrates in EPS extracted from Pyr-grown M.g. SN12 and BaP did not exhibit any significant differences. This is not consistent with the results obtained by Oberoi and Philip (2018), who reported that the ratio of proteins to carbohydrates in EPS varied from 1.87 to 2.71 with an increase in quinoline concentration from 100 to $500 \mathrm{mg} \mathrm{L}^{-1}$. 
Stimulation of EPS secretion by PAHs was confirmed by Hu et al. (2019), who reported that toxic aromatics stimulated microorganisms to secrete EPS, which subsequently formed a dense protective layer to mitigate the toxicity of aromatics that were added to the system (Hu et al. 2019). This dense protective layer allows microorganisms to adapt to toxic environments, leading to gradual degradation of toxic compounds (Kong et al. 2017).

Significantly varying composition of EPS with an increase in Pyr and BaP concentrations demonstrates that the growth of M.g. SN12 was dependent on PAH concentration. Lower PAH concentrations (Pyr, $\leq 80$ $\left.\mathrm{mg} \mathrm{L}^{-1} ; \mathrm{BaP}, \leq 20 \mathrm{mg} \mathrm{L}^{-1}\right)$ in the medium promoted the growth of M.g. SN12, whereas higher PAH concentrations ( $\mathrm{Pyr}, 80-120 \mathrm{mg} \mathrm{L}^{-1} ; \mathrm{BaP}, 20-120 \mathrm{mg} \mathrm{L}^{-1}$ ) did not. The variations in M.g. SN12 growth were inconsistent with those reported by Chen et al. (2010). According to Chen et al. (2010), the growth rate of Acinetobacter junii decreased with the increase in pyrene concentration from $50 \mu \mathrm{g} \mathrm{mL}^{-1}$ to 200 $\mu \mathrm{g} \mathrm{mL}^{-1}$, and was completely inhibited when pyrene concentration reached $400 \mu \mathrm{g} \mathrm{mL}^{-1}$. Similarly, the live cell proportion in sludge significantly decreased to approximately $50 \%, 35 \%$, and $20 \%$, when the concentration of aromatics increased to $30 \mathrm{mg} \mathrm{L}^{-1}, 60 \mathrm{mg} \mathrm{L}^{-1}$, and $80 \mathrm{mg} \mathrm{L}^{-1}$, respectively (Hu et al. 2019). Furthermore, although the bacterial consortium 1-18-1 grown on $\mathrm{BaP}$ remained in the lag phase for $14 \mathrm{~d}$ before reaching the log phase, the growth rate of bacterial consortium was better on Pyr than on $\mathrm{BaP}$ (Sun et al. 2010). Nonetheless, while several bacterial species, including Mycobacterium strains, can grow on a broad range of hydrocarbons using PAHs as the sole source of carbon and energy, the effects of PAHs on the variations in EPS composition are not well documented (Juhasz et al. 1997; Sun et al. 2010).

\subsubsection{Infrared spectra of different EPS extracts}

Figure 2 illustrates FTIR spectra of the EPS samples extracted from M.g. SN12 with and without exposure to Pyr and BaP. The broad absorption band near 3,500-3,200 $\mathrm{cm}^{-1}$ was attributed to the stretching vibrations of hydroxyl and amino groups in carbohydrates and proteins, respectively. The absorption bands near $1,600-1,700 \mathrm{~cm}^{-1}$ were related to distorted vibrations of $\mathrm{C}(\mathrm{N}) \llbracket \mathrm{O}$ and $\mathrm{N}-\mathrm{H}$ groups in proteins, including the band near $1,400 \mathrm{~cm}^{-1}$. The band at $1,240 \mathrm{~cm}^{-1}$ was assigned to the deformation vibration of $\mathrm{C} \otimes \mathrm{O}$ group of carboxylic acids in acidic polysaccharides. The bands near $1,000-1,100 \mathrm{~cm}^{-1}$ resulted from the combined effects of $\mathrm{C}-\mathrm{N}$ stretching vibrations of primary and secondary amines and $\mathrm{C}-\mathrm{O}$ of sugar derivatives ( $\mathrm{Li}$ et al. 2016). Bands at approximately $600 \mathrm{~cm}^{-1}$ were associated with unsaturated bonds in the sample (Lee et al. 2013; Li et al. 2016). Overall, FTIR analysis indicated that all EPS samples primarily contained proteins, carbohydrates, and humic-like substances. These results are consistent with those reported in 3.1.1 and those reported for EPS extracted from other bacteria and activated sludge (Li et al. 2016).

FTIR spectra of EPS extracted from media with or without Pyr supplementation exhibited shifts in peak positions from $1,100 \mathrm{~cm}^{-1}$ to $1,400 \mathrm{~cm}^{-1}$. Compared with EPS extracted from medium without Pyr, the intensities of main peaks at $3,300 \mathrm{~cm}^{-1}, 1,400 \mathrm{~cm}^{-1}$, and $1,000 \mathrm{~cm}^{-1}$, which are related to proteins and sugar derivatives, became stronger with increasing Pyr concentration. This suggested that Pyr stimulated the production of proteins and carbohydrates in the EPS extracts. Compared to the spectra of EPS 
extracted from the control, the bands near $3,300 \mathrm{~cm}^{-1}$ and $1,400 \mathrm{~cm}^{-1}$, associated with proteins, on the spectrum of EPS extracted from Pyr-grown M.g. SN12-supplemented medium indicated blue shifts, whereas the bands near $1,600 \mathrm{~cm}^{-1}$ exhibited a red shift. The assignments corresponding to these peak shifts verified the variations in functional groups of EPS, including hydroxyl, amine, and carboxyl groups, among media supplemented with different concentrations of Pyr.

The relative intensities and positions of the main peaks for EPS extracted from BaP-grown M.g. SN12 also varied depending on the concentration of $\mathrm{BaP}$ in the medium. Bands near $1,100 \mathrm{~cm}^{-1}$ on the spectra of EPS extracted from BaP-grown M.g. SN12 exhibited a red shift in contrast to EPS extracted from the control. Similarly, the spectrum for EPS extracted from BaP-grown M.g. SN12 as a carbon resource exhibited shifts in peak positions from $1,317 \mathrm{~cm}^{-1}, 1,586 \mathrm{~cm}^{-1}$, and $3363 \mathrm{~cm}^{-1}$ to $1,338 \mathrm{~cm}^{-1}, 1,621$ $\mathrm{cm}^{-1}$, and $3390 \mathrm{~cm}^{-1}$, respectively. The peak at $750 \mathrm{~cm}^{-1}$, corresponding to the stretching vibration of the $\mathrm{C}-\mathrm{Cl}$ group in chloroalkanes, appeared only in the spectra of EPS extracted from the control.

The difference in absorption intensities of these spectra revealed that more proteins and carbohydrates were present in the EPS samples extracted from bacteria grown on PAH-supplemented media compared to that extracted from the control. Moreover, hydroxyl and carboxyl groups are polar charged, contributing to the hydrophilicity of EPS, whereas the functional groups, including aromatic and aliphatic groups, in proteins are non-polar and strongly affect the hydrophobicity of EPS (Liu and Fang 2003; Tian et al. 2019). The hydrophobicity of EPS extracts implies that the surface hydrophobicity of bacterial cells depends on the type of supplements. For example, higher proportions of anthracene in the carbon-source mixture resulted in higher cell surface hydrophobicity and highly hydrophobic mycolic acid profiles of $M$. frederiksbergense LB501T (Wick et al. 2003). Wick et al. (2002) also reported that anthracene-grown cells exhibited 70-fold more surface hydrophobicity on anthracene-covered surfaces than glucose-grown cells (Wick et al. 2002)

\subsubsection{DEEM fluorescence spectroscopy of different EPS extracts}

3DEEM was used for verifying the composition of EPS extracts and identifying their key components. Figure 3 and 4 summarize the results of 3DEEM of all EPS extracts. The detailed peak locations and the intensities of EPS extracts are listed in Table 1. 
Table 1

Peak locations (excitation/emission) and the intensities of the fluorescence EEM spectra for extracted EPS

\begin{tabular}{|c|c|c|c|c|c|}
\hline \multirow[t]{2}{*}{ РAH } & \multirow[t]{2}{*}{ concentration $\left(\mathrm{mg} \mathrm{L}^{-1}\right)$} & \multicolumn{2}{|l|}{ Peak A } & \multicolumn{2}{|l|}{ Peak B } \\
\hline & & $\operatorname{Ex} / \operatorname{Em}(\mathrm{nm})$ & Int. (a.u) & $\operatorname{Ex} / \operatorname{Em}(\mathrm{nm})$ & Int. (a.u) \\
\hline \multirow[t]{6}{*}{ Pyr } & 0 & $225 / 350$ & 136.7 & $275 / 350$ & 202.3 \\
\hline & 10 & $225 / 345$ & 260.8 & $275 / 355$ & 420.8 \\
\hline & 20 & $225 / 345$ & 340.9 & $275 / 355$ & 556.0 \\
\hline & 40 & $225 / 345$ & 340.9 & $275 / 355$ & 387.8 \\
\hline & 80 & $225 / 345$ & 140.8 & $275 / 360$ & 455.2 \\
\hline & 120 & $230 / 375$ & 36.21 & $275 / 355$ & 37.81 \\
\hline \multirow[t]{6}{*}{$\mathrm{BaP}$} & 0 & $225 / 350$ & 136.7 & $275 / 350$ & 202.3 \\
\hline & 10 & $225 / 345$ & 339.7 & $275 / 355$ & 555.8 \\
\hline & 20 & $225 / 345$ & 385.6 & $275 / 350$ & 467.2 \\
\hline & 40 & $225 / 355$ & 156.3 & $275 / 350$ & 129.8 \\
\hline & 80 & $225 / 350$ & 99.04 & $275 / 350$ & 121.7 \\
\hline & 120 & $225 / 345$ & 118.4 & $275 / 350$ & - \\
\hline
\end{tabular}

The fluorescence peaks at excitation/emission wavelengths (Ex/Em) of 220-240/340-400 nm (peak A) and 260-290/300-360 nm (peak B) were assigned to aromatic amino acids and amino acid-like fluorescence, respectively (Chen et al. 2003; Hudson et al. 2008). Moreover, peak A was attributed to simple aromatic amino acids, such as tyrosine, whereas peak B was attributed to soluble microbial byproduct-like materials associated with compounds derived from proteins with aromatic amino acids, such as tryptophan or tyrosine (Sheng and Yu 2006; Hudson et al. 2008). In this study, we evaluated only protein and protein-like substances in the EPS extracts, and excluded humic acid- and fulvic acid-like compounds. This was because the quantity of humic acid- and fulvic acid-like compounds in the EPS extracts was undetectable on the fluorescence spectrophotometer (Hu et al. 2019). Nonetheless, the protein or protein-like fluorescence observed in this study agrees with available EEM data on EPS; however, the escape of the fluorescence peaks for humic acid-e and fulvic acid-like compounds is not (Bourven et al. 2012; Zhou et al. 2013).

When M.g. SN12 was cultured on different concentrations of Pyr and BaP, the intensities of peak A for EPS extracts first increased and then decreased with increasing PAH concentration. In other words, the amount of protein or protein-like substances in EPS extracts was dependent on the concentration of PAHs. The strongest florescence intensity for peak A was observed at an Ex/Em wavelength of 225/345 
$\mathrm{nm}$ when the concentration of Pyr and $\mathrm{BaP}$ was $20 \mathrm{mg} \mathrm{L}^{-1}$, with maximum values of 340.9 a.u. and 385.6 a.u., respectively. Additionally, the intensity of peak A rapidly declined to 36.21 a.u. at $120 \mathrm{mg} \mathrm{L}^{-1}$ Pyr. However, the intensity of peak A first decreased with the increasing BaP concentration from $20 \mathrm{mg} \mathrm{L}^{-1}$ to $80 \mathrm{mg} \mathrm{L}^{-1}$ and then increased to 118.4 a.u at $120 \mathrm{mg} \mathrm{L}^{-1} \mathrm{BaP}$.

Similar trends were observed for the intensity of peak B in all the EPS extracts. The maximum intensity of peak $B$ was 556.0 a.u. at $20 \mathrm{mg} \mathrm{L}^{-1} \mathrm{Pyr}$, whereas the it reached a maximum value of 555.8 a.u. at $10 \mathrm{mg}$ $\mathrm{L}^{-1} \mathrm{BaP}$. Nevertheless, a stronger fluorescence intensity of peak B (455.2 a.u.) was obtained next to the maximum value of 556.0 a.u. at $80 \mathrm{mg} \mathrm{L}^{-1}$ Pyr. Furthermore, peak $B$ escaped detection on the spectrum of EPS extracted from M.g. SN12 grown on $120 \mathrm{mg} \mathrm{L}^{-1}$ BaP-supplemented medium. This can be attributed to the fact that the relative intensity of the peak was undetectable. Nonetheless, the variation in protein-like fluorescence of EPS extracts was consistent with the results reported in section 3.1.1. Moreover, after the addition of Pyr and BaP ( $<40 \mathrm{mg} \mathrm{L}^{-1}$ and $20 \mathrm{mg} \mathrm{L}^{-1}$, respectively), the increase in intensities of tyrosine and tryptophan-containing protein-like substances was similar to that of SMP exposed to 2,6-dichlorophenol or aniline (Li et al. 2016; Hu et al. 2019).

The fluorescence intensity of peak B was significantly higher than that of peak A, especially for EPS extracted from Pyr-grown M.g. SN12. This can be attributed to the fact that the concentration of soluble microbial by-product-like substances associated with tryptophan-like fluorescence was higher than those of tyrosine-like materials (Zhou et al. 2013). Compared to the florescence intensities of peak A and B of EPS extracted from Pyr-grown M.g. SN12, the intensities of these two peaks of EPS extracted from cultures supplemented with BaP rapidly increased and then slowly decreased. Probably, the production of tryptophan-like fluorescence in soluble microbial by-product-like substances was more sensitive to BaP than Pyr (Wang et al. 2001). Additionally, protein concentration in EPS affected the hydrophobicity of the cell surface. Rodrigues et al. (2005) reported that the total protein (TP)-to-exopolysaccharide ratios in bacterial cells growing on phenanthrene were typical of biofilms developed under physicochemical stress, and the maximum value for TP/EPS during growth on phenanthrene (1.9) was lower than that on fluorene (5.5). Similarly, P. putida was able to overcome lower aqueous solubility of phenanthrene by adhering to solid PAHs throughout the production of EPS, thereby promoting the availability and uptake of such hydrophobic compounds, which allows proteins in EPS to increase the availability of PAHs (Rodrigues et al. 2005).

\subsection{Evidence of the presence of glycoproteins in EPS using SDS-PAGE}

SDS-PAGE was used to determine the molecular weight of proteins in the EPS extracts. Figure 5 suggests that some proteins in bacterial cells before and after EPS extraction specifically responded to PAHs. There was a marked difference in the protein bands among the bacteria samples L2-L7 extracted from Pyr-grown bacterial cells (Fig. 5(a)). Compared to the bands in the lanes loaded with bacteria grown without Pyr, bands 2, 4, 5, 6, and 9 were thinner and less intense for bacteria samples grown on $10 \mathrm{mg} \mathrm{L}^{-1}$ 
and $20 \mathrm{mg} \mathrm{L}^{-1} \mathrm{Pyr}$, whereas they were thicker and more intense for bacteria from cultures supplemented with $>40 \mathrm{mg} \mathrm{L}^{-1}$ Pyr. The highest intensity for bands 2, 4, 5, 6, and 9 was obtained when $80 \mathrm{mg} \mathrm{L}^{-1} \mathrm{Pyr}$ was supplemented into the culture medium. However, bands $7,8,11$, and 12 were more intense and thicker with increasing Pyr concentration, but exhibited decreased intensity at Pyr concentrations $>80 \mathrm{mg}$ $\mathrm{L}^{-1}$. Nonetheless, no changes were observed in the intensity of bands 1,3 , and 10 . In case of bacteria samples from BaP-grown M.g. SN12-supplemented media, the intensity of bands 1, 2, 3, 4, 5, and 6 increased up to BaP concentrations of $<20 \mathrm{mg} \mathrm{L}^{-1}$ and then decreased, particularly at a BaP concentration of $120 \mathrm{mg} \mathrm{L}^{-1}$ (Fig. 5(b)). Furthermore, two peaks were observed for bands 7, 8, 9, 10, 11, and 12 in the profiles of different bacteria samples at $20 \mathrm{mg} \mathrm{L}^{-1}$ and $80 \mathrm{mg} \mathrm{L}^{-1} \mathrm{BaP}$ concentrations. Therefore, the molecular weight of proteins present in the bacteria samples was dependent on the concentration of Pyr or BaP in the culture medium.

The proteins in bacterial cells before and after EPS extraction specifically responded to PAHs was indicated in Fig. 5(c). The result showed the protein bands of two bacteria samples after EPS extraction are much in common which states the most molecular weights of proteins were mainly located at 20.1$97.2 \mathrm{kDa}$. In comparison with the bands for bacteria grown on Pyr and $\mathrm{BaP}$ (L8, L9), all bands for bacteria sample after EPS extraction (L10, L11) became weaker and thinner. Moreover, band 6 of bacteria grown on Pyr (L11) was more intense than that of bacteria grown on BaP (L10). Hence, the intensity of proteins in bacteria samples, when Pyr or BaP was supplemented into the culture medium, was affected obviously by EPS. Regarding EPS extracts, there was a marked difference in the protein bands between two EPS samples $(L 12, L 13)$. The intensity of protein bands $4,6,7,9,10$ in the profiles of EPS samples extract from bacterial cultures with Pyr $20 \mathrm{mg} \mathrm{L}^{-1}$ are stronger than those in EPS samples from bacterial cultures with BaP $20 \mathrm{mg} \mathrm{L}^{-1}$. It means that Pyr substrate exhibited less influence on proteins in secreted EPS than Bap substrate. Besides, the number of protein bands in two EPS samples is fewer than that in bacteria samples regardless of whether the EPS were removed or not.

The molecular weight of proteins in the EPS samples (L12, L13) ranged between 20.1-116.0 kDa. A difference in the profiles of EPS extracted from Pyr-grown and BaP-grown cells was that different bands exhibited different intensities at the same PAH concentrations. The proteins bands of bacteria samples agree with the results obtained from 3DEEM, except for the bands in the EPS profile of cells grown in medium supplemented with $80 \mathrm{mg} \mathrm{L}^{-1} \mathrm{BaP}$. The distribution of adjacent primary bands is analogous to the SDS-PAGE profile of $S$. xiamenensis BC01, wherein cellular proteins, with molecular weights in the range $35-55 \mathrm{kDa}$, were closer when the concentration of calcium ions increased from $0 \mathrm{mM}$ to $20 \mathrm{mM}$ (Chen et al. 2015). Furthermore, two protein fractions (bands 4 and 6, with molecular weights of approximately $40 \mathrm{kDa}$ and $50 \mathrm{kDa}$ ) were overexpressed, whereas few protein fractions (bands 5 and 8 ) were suppressed in the presence of Pyr or BaP. The overexpression of protein fractions was not consistent with that of the proteins isolated from Pseudomonas aeruginosa, with molecular weights of approximately $38 \mathrm{kDa}, 24 \mathrm{kDa}, 24 \mathrm{kDa}, 16 \mathrm{kDa}$, and < $14 \mathrm{kDa}$ in the presence of 1,300 ppm of lead (Vimalnath and Subramanian 2018). Nonetheless, there are few reports on the SDS-PAGE profiles of EPS extracted from PAH-degrading bacteria. 


\subsection{Emulsifying activity of EPS extracted from PAH- degrading M.g. SN12}

E24 values for liquid paraffin oil, as a function of EPS concentration, are presented in Table 2. It was observed that EPS extracts exhibited improved emulsion-stabilizing capacity for liquid paraffin oil, and the emulsification activity increased with increase in EPS concentration. This is in agreement with the results of Mathivanan et al. (2020), who revealed that a higher emulsification activity was observed at $1 \%$ EPS concentration for all the tested solvents compared to $0.5 \%$ EPS. Similar observations were made by Vidhyalakshmi et al. (2018), who reported a corresponding increase in the emulsification activity of $P$. fluorescens-derived EPS with increasing EPS concentration, with the highest emulsification activity against diesel and olive oils. 
Table 2

Stability of emulsifying activity of EPS isolated from M.g. SN12 growing on PAH

\begin{tabular}{|c|c|c|c|c|}
\hline $\operatorname{Pyr}\left(\mathrm{mg} \mathrm{L}^{-1}\right)$ & Samples & $\mathrm{TOC}\left(\mathrm{mg} \mathrm{L}^{-1}\right)$ & Hydrocarbon/oil & $E_{24}(\%)^{a}$ \\
\hline 0 & EPS1 & $637.8 \pm 8.8$ & Liquid paraffin oil & $41.85 \pm 3.47^{c}$ \\
\hline 10 & EPS2 & $740.7 \pm 13.8$ & Liquid paraffın oil & $45.92 \pm 4.63^{c}$ \\
\hline 20 & EPS3 & $897.5 \pm 24.3$ & Liquid paraffın oil & $53.09 \pm 6.92^{b}$ \\
\hline 40 & EPS4 & $947.3 \pm 12.1$ & Liquid paraffin oil & $69.62 \pm 7.89^{a}$ \\
\hline 80 & EPS5 & $1005.6 \pm 22.6$ & Liquid paraffin oil & $70.76 \pm 9.85^{a}$ \\
\hline 120 & EPS6 & $481.5 \pm 13.5$ & Liquid paraffin oil & $33.58 \pm 3.90^{d}$ \\
\hline $\mathrm{BaP}\left(\mathrm{mg} \mathrm{L}^{-1}\right)$ & Samples & $\mathrm{TOC}\left(\mathrm{mg} \mathrm{L}^{-1}\right)$ & Hydrocarbon/oil & $E_{24}(\%)$ \\
\hline 0 & EPS1 & $637.8 \pm 8.8$ & Liquid paraffin oil & $41.85 \pm 3.47^{b}$ \\
\hline 10 & EPS2 & $712.9 \pm 10.6$ & Liquid paraffin oil & $43.08 \pm 4.21^{b}$ \\
\hline 20 & EPS3 & $876.2 \pm 12.1$ & Liquid paraffin oil & $51.65 \pm 7.45^{a}$ \\
\hline 40 & EPS4 & $835.4 \pm 11.6$ & Liquid paraffin oil & $49.54 \pm 5.32^{a}$ \\
\hline 80 & EPS5 & $422.0 \pm 10.5$ & Liquid paraffin oil & $32.75 \pm 3.28^{c}$ \\
\hline 120 & EPS6 & $407.8 \pm 13.6$ & Liquid paraffin oil & $30.84 \pm 3.61^{c}$ \\
\hline
\end{tabular}

WThe results are expressed as percentages of the total occupied by the emulsion. The values of the averages of at least three determinations

Values in bold: emulsifier index (E24) with values above $50 \%$

Lower cases show difference between Tukey (5\%) test.

Values after \pm shows standard deviation

The thickest emulsion layer $(70.76 \mathrm{~mm})$, with an E24 value of $70.76 \%$, was obtained when EPS yield of Pyr-grown M.g. SN12 increased to $1,005.6 \mathrm{mg} \mathrm{L}^{-1}$. However, the emulsion isolated from EPS extracted from the culture supplemented with $120 \mathrm{mg} \mathrm{L}^{-1} \mathrm{Pyr}$, with an yield of $481.5 \mathrm{mg} \mathrm{L}^{-1}$, was weaker and less stable. In the present study, $51.65 \%$ emulsifying activity was observed in EPS extracted from the cells grown on $20 \mathrm{mg} \mathrm{L}^{-1} \mathrm{BaP}$, with an yield of $876.2 \mathrm{mg} \mathrm{L}^{-1}$, which was significant higher than the emulsifying activity of other EPS extracts. Comparison to the EPS extracted from Pyr-grown M.g. SN12, the emulsifying activity of EPS extracted from BaP-grown bacteria was slightly lower, which agrees with EPS yield. Hence, the emulsification index of EPS extracts was positively correlated with the yield of EPS extracts. 
The emulsifying activity of EPS extracts can be attributed to specific functional groups, such as 6deoxyhexose and acetyl moieties, which confer hydrophobicity to EPS and consequently contribute to its emulsifying capacity (Maalej et al. 2016). Some functional groups in the proteins of EPS extracts may also contribute to its emulsifying capacity. The present study indicated that the emulsifying activity of EPS extracts was dependent on the type of substrate used for bacterial growth, which is consistent with other reports, wherein Rhizobium tropici grew on hydrocarbon-based substrates and marine bacteria employed substrate-specific hydrocarbon metabolism (Suresh Kumar et al. 2007; Castellane et al. 2017). The criterion for determining the emulsion-stabilizing ability of an emulsifier is to evaluate its ability to maintain at least $50 \%$ of the original volume of the emulsion for $24 \mathrm{~h}$ (Willumsen and Karlson 1997; Camacho-Chab et al. 2013). Considering this criterion, EPS extracted from PAH-degrading M.g. SN12 exhibits promising characteristics, with an improve ability of emulsifying PAHs on the surface of soil particles. As there are no studies on the emulsifying capacity of EPS produced by M.g. SN12 grown on hydrocarbons, these findings are important as they demonstrate the emulsifying ability of EPS and other uses for EPS products.

\subsection{Microscopic characterization of different EPS extracts}

Figure 6 shows scanned images of the surface of bacterial cell $(10,000 \mathrm{X})$ and different EPS extracts $(5,000 X)$. EPS, with an appearance similar to a mucus layer, surrounded the cell wall of M.g. SN12. The inner layer of EPS exhibited a determinate shape and was tightly bound to the cell wall, whereas the outer layer was loose and resembled a dispersible slime layer without an obvious edge. SEM images of all EPS extracts resembled sheets of overlaid polysaccharides, exhibiting a compact structure with smooth surfaces. The structure was similar to EPS extracted from Lactobacillus plantarum KF5, which exhibits a compact structure with smooth surface (Wang et al. 2010), but was different from EPS extracted from Lactobacillus kefiranofacien ZW3 and Leuconostoc citreum N21, which resemble a thin film with smooth and glittering surface (Ahmed et al. 2013; Yang et al. 2019). The uneven, less porous surface of M.g. SN12 EPS was not similar to that of EPS extracted from Bacillus cereus KMS3-1, Streptomyces griseorubens GD5, and L. plantarum KF5, which exhibit an irregular, highly porous, web-like structure (Wang et al. 2010; Vinothini et al. 2019; Mathivanan et al. 2020).

At a magnification of 5,000X, EPS extracted from the control was more fragile non-destructive compared with those extracted from Pyr- or BaP-grown M.g. SN12. Furthermore, EPS extracted from Pyr-grown M.g. SN12 fractured into pieces, and exhibited different levels of fragmentation with increasing concentration of Pyr; EPS extracted from M.g. SN12 grown on $80 \mathrm{mg} \mathrm{L}^{-1}$ Pyr was the most fragile, with less pores on its surface. However, less fragile and more compact EPS was observed at $120 \mathrm{mg} \mathrm{L}^{-1}$ Pyr. By contrast, the fragility of EPS obtained from BaP-grown M.g. SN12 increased with an increase in BaP concentration, with the most fragile and loose EPS observed at $40 \mathrm{mg} \mathrm{L}^{-1} \mathrm{BaP}$. Moreover, EPS was granular at $80 \mathrm{mg} \mathrm{L}^{-1}$ $\mathrm{BaP}$. Thus, the surface morphology of EPS was affected by the concentration of Pyr and BaP.

Compared with the EPS extracted from Pyr-grown M.g. SN12, the EPS extracted from BaP-grown M.g. SN12 was more fragile and softer, especially from M.g. SN12 grown on 0-40 mg L-1 BaP. Furthermore, the 
EPS extracted from M.g. SN12 grown on PAH were not uniform in size, with few irregular pores on the surface of EPS extracted from M.g. SN12 grown on $120 \mathrm{mg} \mathrm{L}^{-1}$ PAHs. This can be attributed to the fact that some Pyr or BaP was distributed in the EPS, as demonstrated by Hu et al. (2019), who identified aromatics in EPS layers and revealed that the concentration of aromatics gradually decreased from SEPS, to LB-EPS, and TB-EPS. To the best of our knowledge, this is the first report on the texture profile of EPS samples extracted from M.g. SN12 grown on PAHs.

\section{Conclusions}

EPS production in M.g. SN12 can be improved by the addition of Pyr and BaP in the culture medium. It was observed that, under the different culture conditions, EPS extracts exhibited distinct properties. Increase in the concentrations of $\operatorname{Pyr}\left(0-80 \mathrm{mg} \mathrm{L}^{-1}\right)$ or $\mathrm{BaP}\left(0-20 \mathrm{mg} \mathrm{L}^{-1}\right)$ in the culture medium resulted in an increase in EPS production and the concentrations of proteins and polysaccharides in the EPS. However, EPS yield and protein and polysaccharide concentrations exhibited an opposite tread at Pyr $>80$ $\mathrm{mg} \mathrm{L}^{-1}$ and $\mathrm{BaP}>120 \mathrm{mg} \mathrm{L}^{-1}$. These findings were verified by 3DEEM and SDS-PAGE of the different EPS extracts. Furthermore, the emulsifying activity of EPS extracts exhibited similar variations with the production of EPS or the concentrations of proteins and polysaccharides present in EPS. EPS extracts exhibited different levels of fragmentation, with EPS extracted from BaP-grown M.g. SN12 being more fragile and softer than that extracted from Pyr-grown M.g. SN12. The changes in EPS profiles explain the possible defensive mechanism of M.g. SN112 against Pyr and BaP exposure. Herein, Pyr or BaP affected the outer membrane of the bacterial cells, which altered their protein pattern and resulted in EPS secretion. These findings will improve the understanding and provide insights into the variations in EPS, which can be used for the bioremediation of PAH-polluted soils.

\section{Declarations}

\section{Ethics approval and consent to participate}

Not applicable

\section{Consent for publication}

Not applicable

\section{Availability of data and materials}

Not applicable

\section{Competing interests}

The authors declare that they have no competing interest.

\section{Funding}


This work was supported by the Natural Science Foundation of China (No. 41673132) and the Innovation Program in Sciences and Technologies for Young and Middle-aged Scientists (grant number RC200123).

\section{Authors' contributions}

Chunyun Jia carried out the experiment and was a major contributor in writing the manuscript.

Changfei Liu took part in the design of the experiment and analysis of collected samples.

Zongqiang Gong took part in the analysis of three dimensional excitation and emission matrix florescence of EPS extracts.

Xiaojun Li took part in the data interpretation and writing the manuscript.

Zijun Ni developed the characterization of EPS extracts.

All authors read and approved the final manuscript.

\section{Acknowledgements}

We gratefully acknowledge Associate Professor Liping Weng for her comments and suggestions. We appreciated Xinyan Li for her help during the cultivation of bacteria. This work was supported by the Natural Science Foundation of China (No. 41673132) and the Innovation Program in Sciences and Technologies for Young and Middle-aged Scientists (grant number RC200123).

\section{References}

1. Aguilera A, Souza-Egipsy V, San Martín-Uriz P, Amils R (2008) Extraction of extracellular polymeric substances from extreme acidic microbial biofilms. Appl Microbiol Biotechnol 78:1079-1088

2. Ahmed Z, Wang YP, Anjum N et al (2013) Characterization of exopolysaccharide produced by Lactobacillus kefiranofaciens ZW3 isolated from Tibet kefir - Part II. Food Hydrocoll 30:343-350

3. Aquino SF, Stuckey DC (2004) Soluble microbial products formation in anaerobic chemostats in the presence of toxic compounds. Water Res 38:255-266

4. Bai L, Xu H, Wang C et al (2016) Extracellular polymeric substances facilitate the biosorption of phenanthrene on cyanobacteria Microcystis aeruginosa. Chemosphere 162:172-180

5. Bourven I, Costa G, Guibaud G (2012) Qualitative characterization of the protein fraction of exopolymeric substances (EPS) extracted with EDTA from sludge. Bioresour Technol 104:486-496

6. Camacho-Chab JC, Guézennec J, Chan-Bacab MJ et al (2013) Emulsifying activity and stability of a non-toxic bioemulsifier synthesized by Microbacterium sp. MC3B-10. Int J Mol Sci 14:18959-18972

7. Castellane TCL, Campanharo JC, Colnago LA et al (2017) Characterization of new exopolysaccharide production by Rhizobium tropici during growth on hydrocarbon substrate. Int $\mathrm{J}$ Biol Macromol 96:361-369 
8. Cescutti P, Toffanin R, Pollesello P, Sutherland IW (1999) Structural determination of the acidic exopolysaccharide produced by a Pseudomonas sp. strain 1.15. Carbohydr Res 315:159-168

9. Chen T, Zhou Y, Ng I et al (2015) Formation and characterization of extracellular polymeric substance from Shewanella xiamenensis BC01 under calcium stimulation. J Taiwan Inst Chem Eng 57:175181

10. Chen W, Westerhoff P, Leenheer JA, Booksh K (2003) Fluorescence excitation-emission matrix regional integration to quantify spectra for dissolved organic matter. Environ Sci Technol 37:57015710

11. Chen Y, Yao J, Chen K et al (2010) Microcalorimetric investigation of the toxic action of pyrene on the growth of PAH-degrading bacteria Acinetobacter junii. J Environ Sci Health A Tox Hazard Subst Environ Eng 45:668-673

12. Frølund B, Griebe T, Nielsen PH (1995) Enzymatic activity in the activated-sludge floc matrix.Appl Microbiol Biotechnol43:755-761

13. Frølund B, Palmgren R, Keiding K, Nielsen PH (1996) Extraction of extracellular polymers from activated sludge using a cation exchange resin. Water Res 30:1749-1758. http://doi.org/Doi10.1016/0043-1354(95)00323-1

14. Gan S, Lau EV, Ng HK (2009) Remediation of soils contaminated with polycyclic aromatic hydrocarbons (PAHs). J Hazard Mater 172:532-549

15. Ghosh P, Mukherji S (2021) Growth kinetics of Pseudomonas aeruginosa RS1 on fluorene and dibenzothiophene, concomitant degradation kinetics and uptake mechanism. 3 Biotech 11:195

16. González-González M, Mayolo-Deloisa K, Rito-Palomares M, Winkler R (2011) Colorimetric protein quantification in aqueous two-phase systems. Process Biochem 46:413-417

17. Guibaud G, van Hullebusch E, Bordas F et al (2009) Sorption of Cd(II) and Pb(II) by exopolymeric substances (EPS) extracted from activated sludges and pure bacterial strains: Modeling of the metal/ligand ratio effect and role of the mineral fraction. Bioresour Technol 100:2959-2968

18. Haritash AK, Kaushik CP (2009) Biodegradation aspects of polycyclic aromatic hydrocarbons (PAHs): A review. J Hazard Mater 169:1-15

19. Henriques ID, Love NG (2007) The role of extracellular polymeric substances in the toxicity response of activated sludge bacteria to chemical toxins. Water Res 41:4177-4185

20. Hong J, Oren Z, Shai Y (1999) Structure and organization of hemolytic and nonhemolytic diastereomers of antimicrobial peptides in membranes. Biochemistry 38:16963-16973. http://doi.org/Doi10.1021/Bi991850y

21. Hu Q, Zhou N, Rene ER et al (2019) Stimulation of anaerobic biofilm development in the presence of low concentrations of toxic aromatic pollutants. Bioresour Technol 281:26-30

22. Hudson N, Baker A, Ward D et al (2008) Can fluorescence spectrometry be used as a surrogate for the Biochemical Oxygen Demand (BOD) test in water quality assessment? An example from South West England. Sci Total Environ 391:149-158 
23. Jia CY, Li PJ, Li XJ et al (2011) Degradation of pyrene in soils by extracellular polymeric substances (EPS) extracted from liquid cultures. Process Biochem 46:1627-1631

24. Jia CY, Li XJ, Zhang LF et al (2017) Extracellular polymeric substances from a fungus are more effective than those from a bacterium in polycyclic aromatic hydrocarbon biodegradation. Water Air Soil Pollut 228:228http. doi.org/Artn 19510.1007/S11270-017-3330-8

25. Johnsen AR, Wick LY, Harms H (2005) Principles of microbial PAH-degradation in soil. Environ Pollut 133:71-84

26. Juhasz AL, Britz ML, Stanley GA (1997) Degradation of fluoranthene, pyrene, benz[a]anthracene and dibenz[a,h]anthracene by Burkholderia cepacia.J Appl Microbiol83:189-198

27. Kong Q, He X, Feng Y et al (2017) Pollutant removal and microorganism evolution of activated sludge under ofloxacin selection pressure. Bioresour Technol 241:849-856

28. Laemmli UK (1970) Cleavage of structural proteins during the assembly of the head of bacteriophage T4.Nature227:680-685

29. Lee BM, Shin HS, Hur J (2013) Comparison of the characteristics of extracellular polymeric substances for two different extraction methods and sludge formation conditions. Chemosphere 90:237-244

30. Li K, Wei D, Yan T et al (2016) Responses of soluble microbial products and extracellular polymeric substances to the presence of toxic 2,6-dichlorophenol in aerobic granular sludge system. J Environ Manage 183:594-600

31. Li XY, Yang SF (2007) Influence of loosely bound extracellular polymeric substances (EPS) on the flocculation, sedimentation and dewaterability of activated sludge. Water Res 41:1022-1030

32. Liang Z, Li W, Yang S, Du P (2010) Extraction and structural characteristics of extracellular polymeric substances (EPS), pellets in autotrophic nitrifying biofilm and activated sludge. Chemosphere 81:626-632

33. Liu A, Ahn IS, Mansfield C et al (2001) Phenanthrene desorption from soil in the presence of bacterial extracellular polymer: Observations and model predictions of dynamic behavior. Water Res 35:835843. http://doi.org/Doi10.1016/S0043-1354(00)00324-9

34. Liu Y, Fang HHP (2003) Influences of extracellular polymeric substances (EPS) on flocculation, settling, and dewatering of activated sludge. Crit Rev Environ Sci Technol 33:237-273. http://doi.org/Doi10.1080/10643380390814479

35. Maalej H, Hmidet N, Boisset C et al (2016) Rheological and emulsifying properties of a gel-like exopolysaccharide produced by Pseudomonas stutzeri AS22. Food Hydrocoll 52:634-647

36. Mathivanan K, Chandirika JU, Mathimani T et al (2020) Optimization, compositional analysis, and characterization of exopolysaccharides produced by multi-metal resistant Bacillus cereus KMS3-1. Carbohydr Polym:227. http. doi.org/UNSP 11536910.1016/j.carbpol.2019.115369

37. Moretto C, Castellane TCL, Lopes EM et al (2015) Chemical and rheological properties of exopolysaccharides produced by four isolates of rhizobia. Int J Biol Macromol 81:291-298 
38. Oberoi AS, Philip L (2018) Variation in cell surface characteristics and extracellular polymeric substances during the biodegradation of monocyclic and heterocyclic aromatic hydrocarbons in single and multi-substrate systems. Environ Technol 39:3115-3126

39. Pan XL, Liu J, Zhang DY (2010) Binding of phenanthrene to extracellular polymeric substances (EPS) from aerobic activated sludge: A fluorescence study. Colloids Surf B Biointerfaces 80:103-106

40. Rodrigues AC, Wuertz S, Brito AG, Melo LF (2005) Fluorene and phenanthrene uptake by Pseudomonas putida ATCC 17514: Kinetics and physiological aspects. Biotechnol Bioeng 90:281289

41. Sack U, Heinze TM, Deck J et al (1997) Comparison of phenanthrene and pyrene degradation by different wood-decaying fungi.Appl Environ Microbiol63:3919-3925

42. Sheng GP, Yu HQ (2006) Characterization of extracellular polymeric substances of aerobic and anaerobic sludge using three-dimensional excitation and emission matrix fluorescence spectroscopy. Water Res 40:1233-1239

43. Sheng GP, Yu HQ, Yu Z (2005) Extraction of extracellular polymeric substances from the photosynthetic bacterium Rhodopseudomonas acidophila. Appl Microbiol Biotechnol 67:125-130

44. Sheng GP, Zhang ML, Yu HQ (2008) Characterization of adsorption properties of extracellular polymeric substances (EPS) extracted from sludge. Colloids Surf B Biointerfaces 62:83-90

45. Sun R, Jin J, Sun G et al (2010) Screening and degrading characteristics and community structure of a high molecular weight polycyclic aromatic hydrocarbon-degrading bacterial consortium from contaminated soil. J Environ Sci (China) 22:1576-1585

46. Suresh Kumar AS, Mody K, Jha B (2007) Evaluation of biosurfactant/bioemulsifier production by a marine bacterium. Bull Environ Contam Toxicol 79:617-621

47. Tian X, Shen Z, Han Z, Zhou Y (2019) The effect of extracellular polymeric substances on exogenous highly toxic compounds in biological wastewater treatment: An overview. Bioresour Technol Rep $5: 28-42$

48. Tourney J, Ngwenya BT, Fred Mosselmans JW, Magennis M (2009) Physical and chemical effects of extracellular polymers (EPS) on Zn adsorption to Bacillus licheniformis S-86. J Colloid Interface Sci 337:381-389

49. Urai M, Anzai H, Ogihara J et al (2006) Structural analysis of an extracellular polysaccharide produced by Rhodococcus rhodochrous strain S-2. Carbohydr Res 341:766-775

50. Vidhyalakshmi R, Valli Nachiyar C, Narendra Kumar G et al (2018) Production, characterization and emulsifying property of exopolysaccharide produced by marine isolate of Pseudomonas fluorescens. Biocatal Agric Biote 16:320-325

51. Vimalnath $\mathrm{S}$, Subramanian $\mathrm{S}$ (2018) Studies on the biosorption of $\mathrm{Pb}$ (II) ions from aqueous solution using extracellular polymeric substances (EPS) of Pseudomonas aeruginosa. Colloids Surf B Biointerfaces 172:60-67

52. Vinothini G, Latha S, Arulmozhi M, Dhanasekaran D (2019) Statistical optimization, physio-chemical and bio-functional attributes of a novel exopolysaccharide from probiotic Streptomyces griseorubens 
GD5. Int J Biol Macromol 134:575-587

53. Wang SY, Xu XL, Liu QL, Xie YS (2001) The Application of Fluorescence Spectroscopy in the Study on Protein Conformation.Progr Chem-China13:257-260

54. Wang Y, Li C, Liu P et al (2010) Physical characterization of exopolysaccharide produced by Lactobacillus plantarum KF5 isolated from Tibet Kefir. Carbohydr Polym 82:895-903

55. Wick LY, Pasche N, Bernasconi SM et al (2003) Characterization of multiple-substrate utilization by anthracene-degrading Mycobacterium frederiksbergense LB501T. Appl Environ Microbiol 69:61336142

56. Wick LY, Wattiau P, Harms H (2002) Influence of the growth substrate on the mycolic acid profiles of mycobacteria. Environ Microbiol 4:612-616. http://doi.org/DOI10.1046/j.1462-2920.2002.00340.x

57. Willumsen PA, Karlson U (1997) Screening of bacteria, isolated from PAH-contaminated soils, for production of biosurfactants and bioemulsifiers. Biodegradation 7:415-423. http://doi.org/Doi10.1007/Bf00056425

58. Yang Y, Feng F, Zhou Q et al (2019) Isolation, purification, and characterization of exopolysaccharide produced by Leuconostoc citreum N21 from dried milk cake. Trans Tianjin Univ 25:161-168

59. Zhang JQ, Dong YH (2008) Effect of low-molecular-weight organic acids on the adsorption of norfloxacin in typical variable charge soils of China. J Hazard Mater 151:833-839

60. Zhang Z, Xia S, Wang X et al (2009) A novel biosorbent for dye removal: Extracellular polymeric substance (EPS) of Proteus mirabilis TJ-1. J Hazard Mater 163:279-284

61. Zheng CG, He JL, Wang YL et al (2011) Hydrocarbon degradation and bioemulsifier production by thermophilic Geobacillus pallidus strains. Bioresour Technol 102:9155-9161

62. Zhou J, Wang JJ, Baudon A, Chow AT (2013) Improved fluorescence excitation-emission matrix regional integration to quantify spectra for fluorescent dissolved organic matter. J Environ Qual 42:925-930

63. Zhu L, Qi HY, Lv ML et al (2012) Component analysis of extracellular polymeric substances (EPS) during aerobic sludge granulation using FTIR and 3D-EEM technologies. Bioresour Technol 124:455459

\section{Figures}



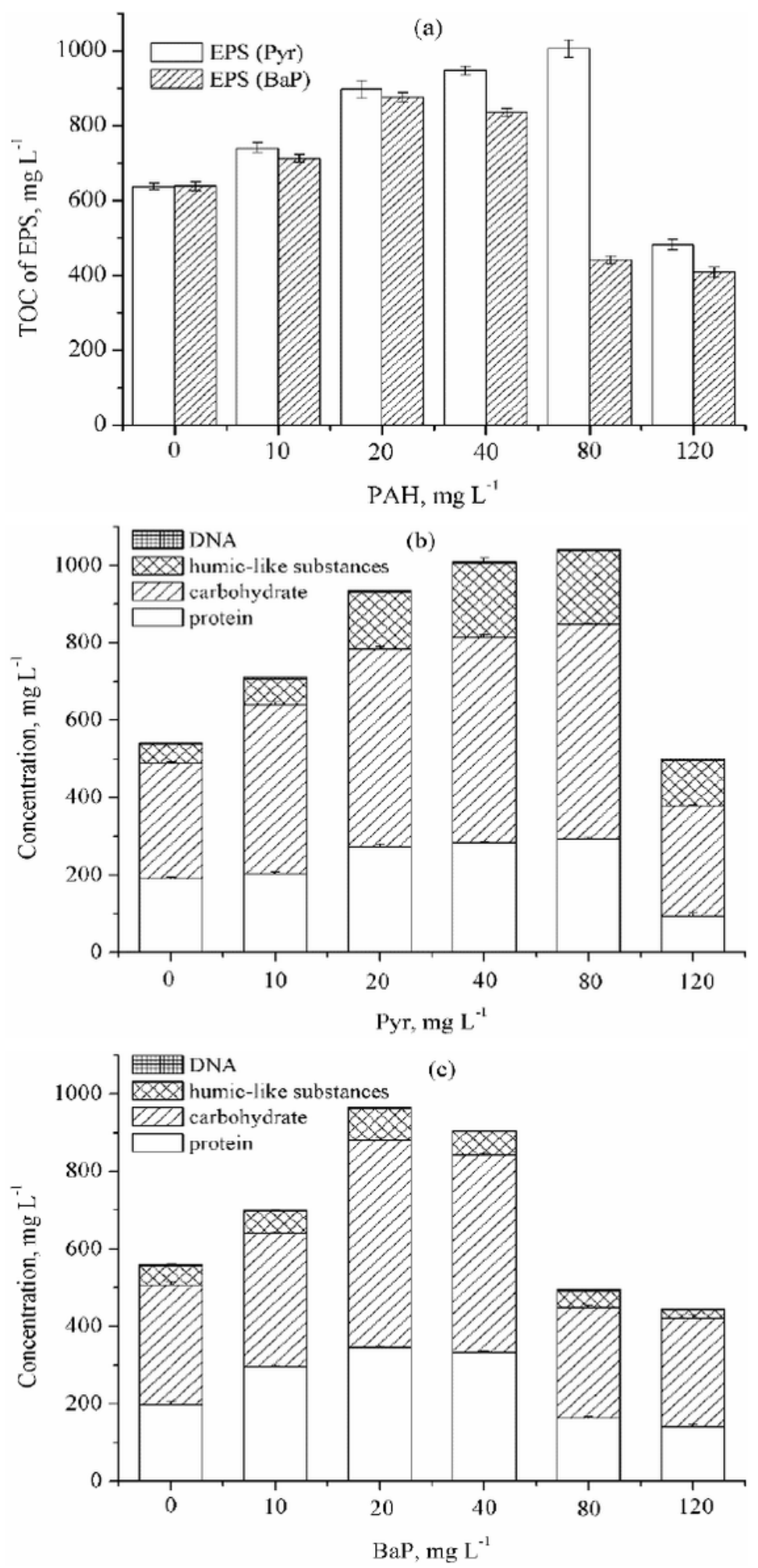

Figure 1

Composition of EPS isolated from M.g. SN12 grown on PAHs 


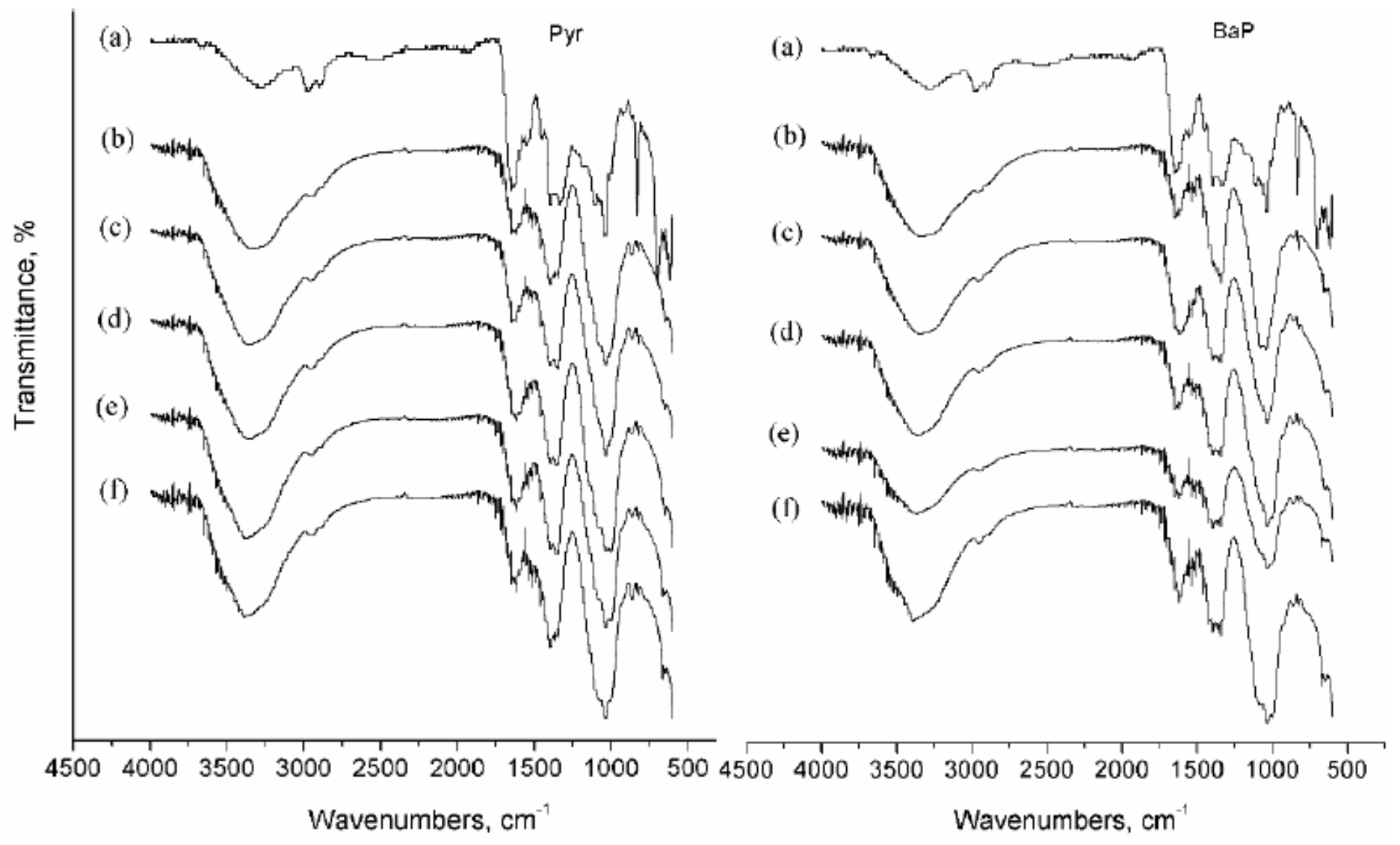

Figure 2

FTIR spectra of EPS from M.g. SN12 with Pyr or BaP as co-substrate (a) 0 mg L-1; (b) 10 mg L-1; (c) 20 mg L-1; (d) 40 mg L-1; (e) 80 mg L-1; (f) 120 mg L-1 

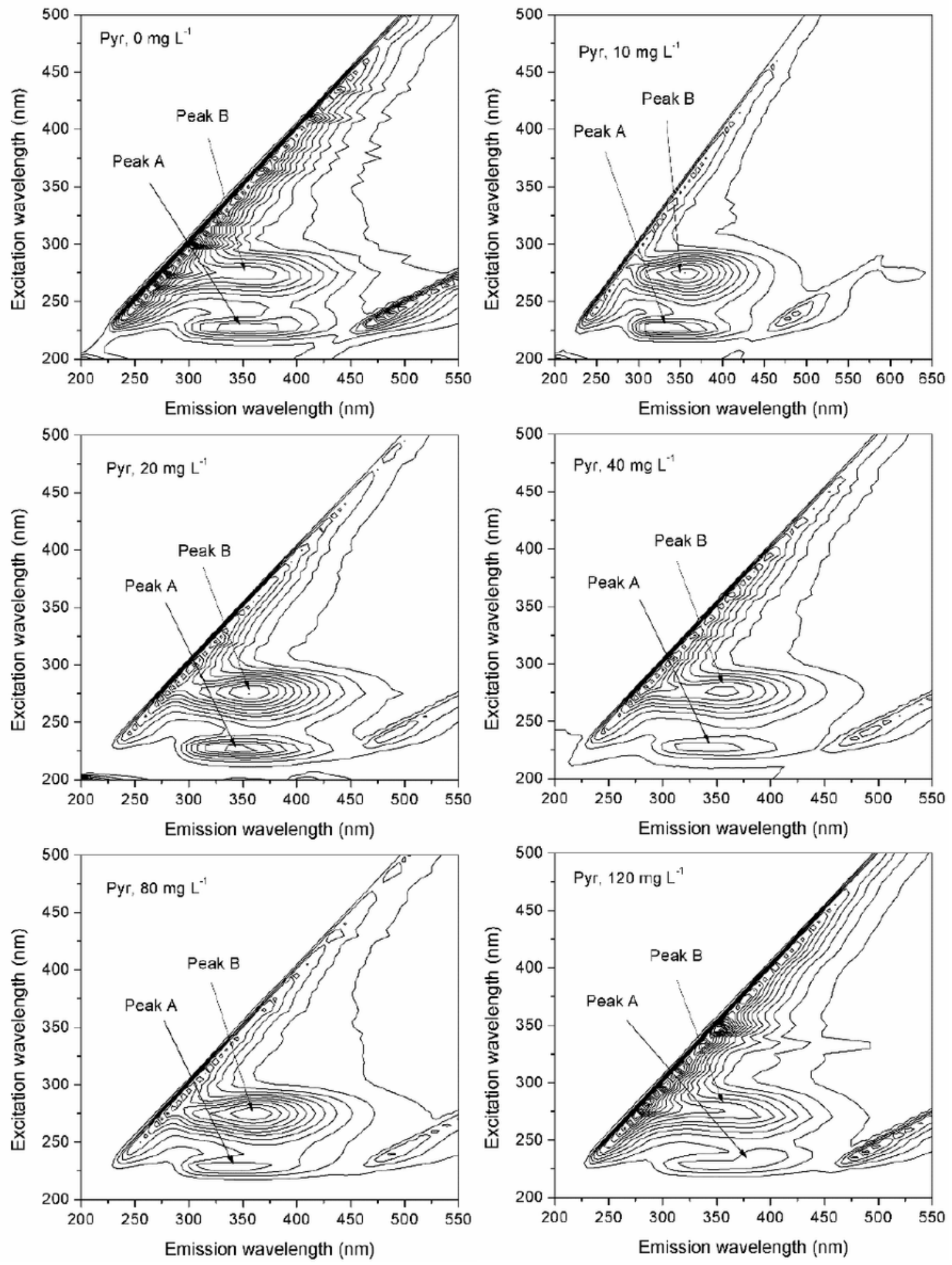

\section{Figure 3}

EEM contours of EPS isolated from M.g. SN12 grown on Pyr. (a) Pyr, 0 mg.L-1; (b) Pyr, 10 mg.L-1; (c) Pyr, $20 \mathrm{mg} \cdot \mathrm{L}-1$; (d) Pyr, $40 \mathrm{mg} \cdot \mathrm{L}-1$; (e) Pyr, $80 \mathrm{mg} \cdot \mathrm{L}-1$;(f) Pyr, $120 \mathrm{mg} \cdot \mathrm{L}-1$. Peak A and Peak B are the fluorescence peaks 

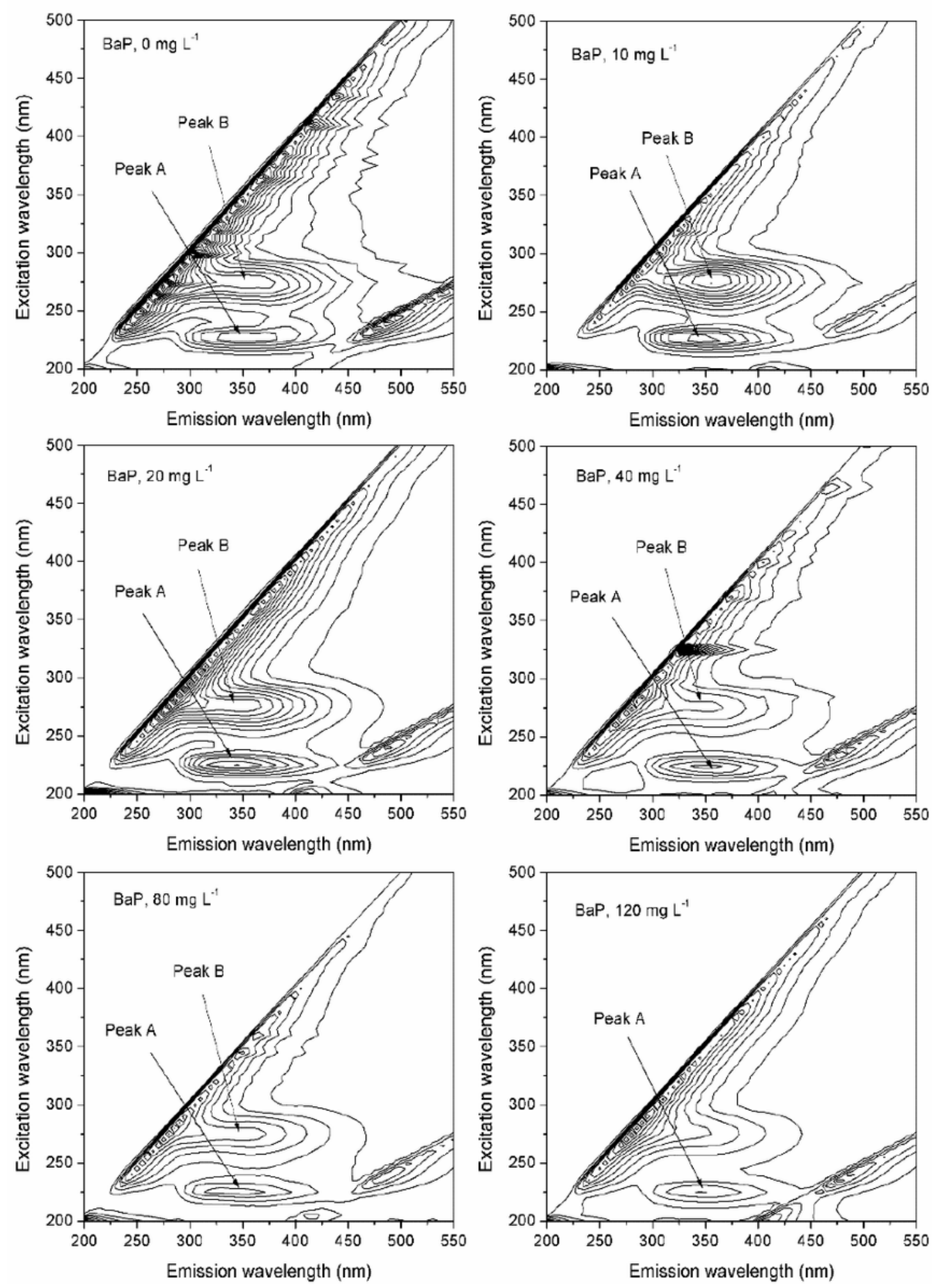

\section{Figure 4}

EEM contours of EPS isolated from M.g. SN12 grown on BaP. (a) BaP, 0 mg.L-1; (b) BaP, $10 \mathrm{mg} \cdot \mathrm{L}-1$; (c) BaP, $20 \mathrm{mg} \cdot \mathrm{L}-1$; (d) BaP, $40 \mathrm{mg} \cdot \mathrm{L}-1$;(e) BaP, $80 \mathrm{mg} \cdot \mathrm{L}-1$;(f) BaP, $120 \mathrm{mg} \cdot \mathrm{L}-1$. Peak A and Peak B are the fluorescence peaks 

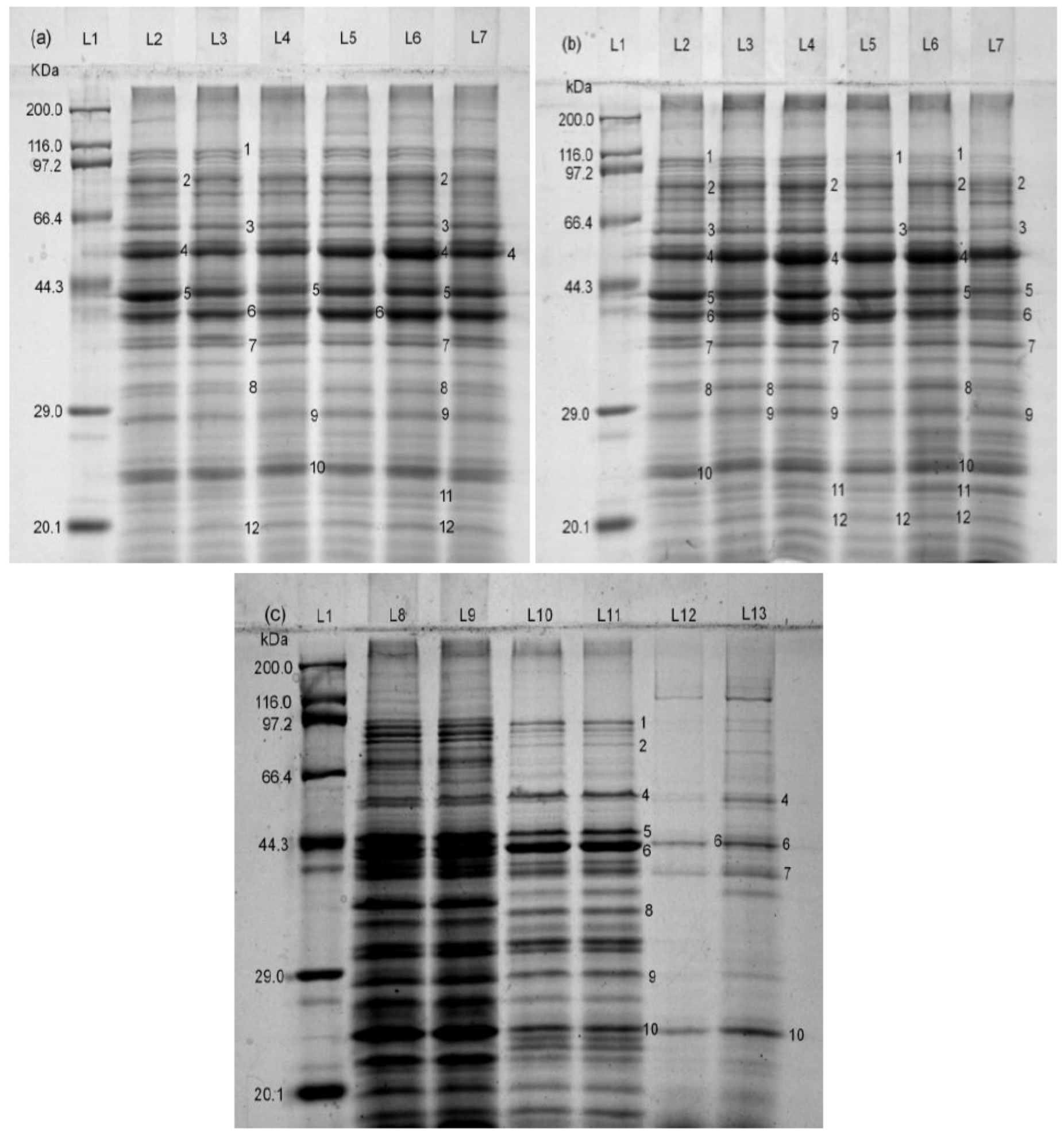

\section{Figure 5}

SDS-PAGE of protein in bacterial cells or EPS with the medium supplemented with (a) Pyr and (b) BaP (L1, maker; L2, 0 mg L-1; L3, 10 mg L-1; L4, 20 mg L-1; L5, 40 mg L-1; L6, 80 mg L-1; L7, 120 mg L-1) , (c) Pyr and BaP (L1, maker; L2, 0 mg L-1; L8, 20 mg L-1 BaP; L9, 20 mg L-1 Pyr; L10, 20 mg L-1 BaP and EPS removed; L11, 20 mg L-1 Pyr and EPS moved; L13, EPS extracts from cultures with 20 mg L-1 BaP; L14, EPS extracts from cultures with $20 \mathrm{mg} \mathrm{L-1} \mathrm{Pyr)}$ 


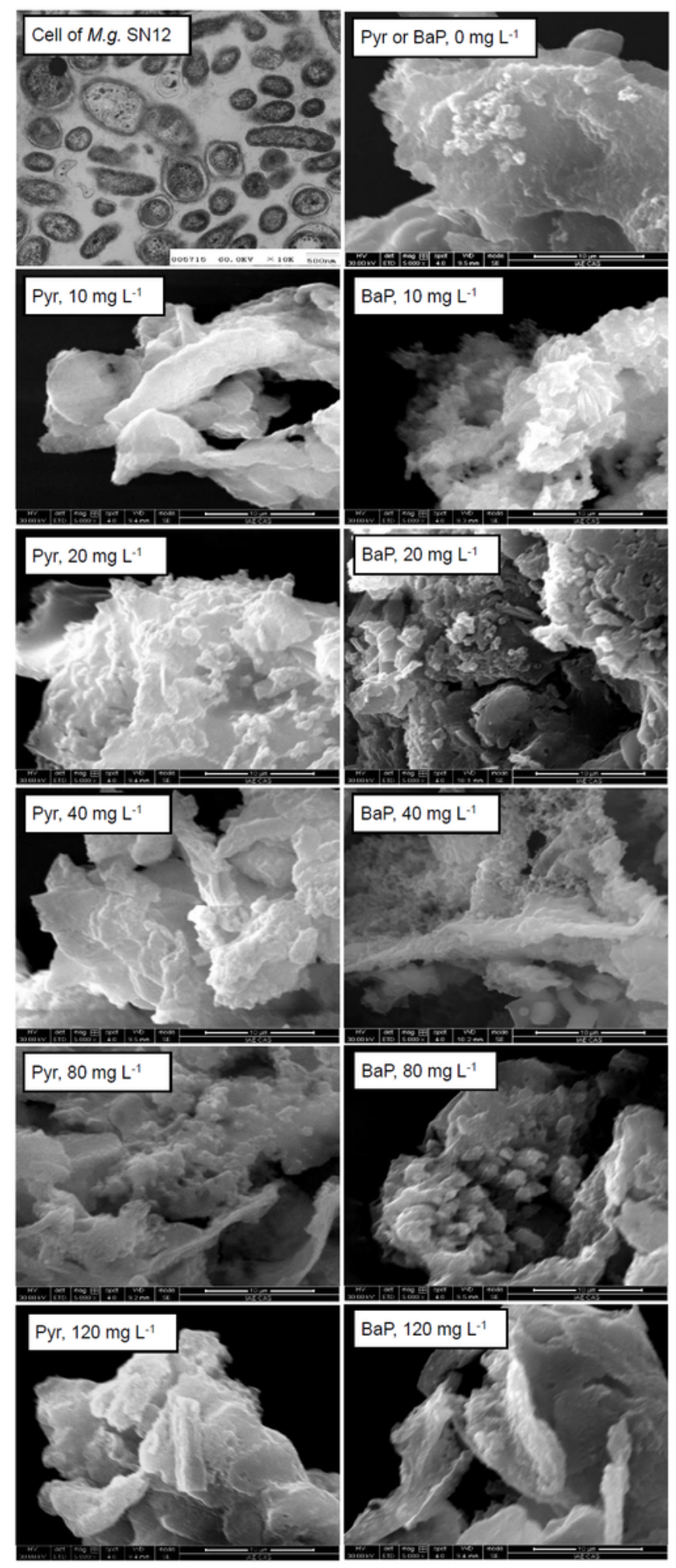

Figure 6

Observations of EPS from M.g. SN12 cultured with different PAH concentrations 